\title{
Efektivitas Pemanfaatan Teknologi Informasi Berbasis E-Commerce Pada Usaha Mikro, Kecil Dan Menengah (Umkm) Produk Pangan Di Kota Banda Aceh
}

\author{
(Effectiveness of E-Commerce Based Information Technology Usaha Mikro, Kecil and \\ Menengah (UMKM) Food Products in Banda Aceh City)
}

\author{
Handhika Kusuma ${ }^{1}$, Lukman Hakim ${ }^{1}$, Agus Nugroho ${ }^{\text {* }}$ \\ Yolanda $^{1}$, Suyanti Kasimin ${ }^{1}$, Widyawati ${ }^{*}$ \\ ${ }^{1}$ Program Studi Agribisnis, Fakultas Pertanian, Universitas Syiah Kuala \\ *Corresponding author: nugroho@unsyiah.ac.id
}

\begin{abstract}
Abstrak. Tujuan penelitian ini yaitu untuk mengetahui efektivitas pemanfaatan Teknologi Informasi berbasis e-commerce pada Usaha Mikro, Kecil, dan Menengah (UMKM) di Kota Banda Aceh. Hasil penelitian memberikan informasi secara umum indikator dukungan pemerintah dianggap masih rendah. Dianggap masih rendah karena progressnya masih sangat lambat terhadap pemanfaatan teknologi informasi berbasis $e$ commerce pada UMKM produk pangan di Kota Banda Aceh. Indikator infrastruktur dalam pemanfaatan Teknologi Informasi berbasis e-commerce dianggap sudah efektif. Dianggap sudah efektif dikarenakan sarana dan prasarana telah dirasakan dan dapat dimanfaatkan oleh pelaku UMKM. Indikator sumber daya manusia dalam pemanfaatan Teknologi Informasi berbasis e-commerce dianggap masih rendah. Hal tersebut terjadi karena masih banyak pelaku UMKM produk pangan yang tidak mengerti dan tidak memahami tentang pemanfaatan Teknologi Informasi yang canggih ini.
\end{abstract}

Kata Kunci: Teknologi Informasi, E-commerce, Usaha Mikro, Kecil dan Menengah

\begin{abstract}
The purpose of this study is to determine the effectiveness of the use of e-commerce-based Information Technology in Usaha Mikro, Kecil dan Menengah (UMKM) in the City of Banda Aceh. The results of the study provided in general information that indicators of government support were still considered low. It is considered still low because the progress is still very slow towards the use of information technology based on e-commerce in food product SMEs in the City of Banda Aceh. Infrastructure indicators in the use of Information Technology based on e-commerce are considered effective. It is considered to be effective because the facilities and infrastructure have been felt and can be utilized by SMEs. Indicators of human resources in the use of information technology based on e-commerce are still considered low. This happens because there are still many MSME food product actors who do not understand or do not understand about the use of this advanced information technology.
\end{abstract}

Keywords: Information Technology, E-commerce, Usaha Mikro, Kecil dan Menengah

\section{PENDAHULUAN}

Pesatnya perkembangan Teknologi Informasi dan komunikasi atau yang dikenal dengan istilah Information and Commnunication Technology (ICT) telah merambah berbagai bidang kehidupan tidak terkecuali bidang bisnis dan perdagangan. Teknologi Informasi adalah teknologi yang digunakan dalam pemrolehan, penyimpanan, pengolahan dan pendistribusian informasi dengan cara elektronik (Collin, 1987 dalam Siregar, 2005). Dengan pemanfaatan Teknologi Informasi produsen dan konsumen dapat terhubung dengan cepat. Media teknologi infromasi untuk berbagai aktifitas kegiatan usaha disebut dengan e-commerce. Kegiatan bisnis yang dilakukan tersebut bisa meliputi pemasaran, promosi. public relation, transaksi, pembayaran, dan penjadwalan pengiriman barang, serta masih cukup terbuka inovasi-inovasi kegiatan bisnis online seiring dengan perkembangan teknologi e-commerce tersebut (Turban, 2001).

E-commerce diartikan sebagai salah satu proses bisnis yang menggunakan elektronik sebagai penghubung antara perusahaan dan konsumen dalam sebuah bentuk transaksi elektronik, dimana pertukaran atau penjualan barang/jasa dan informasi secara elektronik (Fuady 2005 dalam Prasetyo, 2018). Kegiatan pemasaran dengan memanfaatkan 
TI merupakan salah satu alternatif dalam menjual, mempromosikan produk suatu usaha, baik berupa jasa/barang yang akan di distribusikan pada konsumen secara efektif dan efisien. Pemasaran yang efektif dapat meningkatkan volume penjualan dan meningkatkan pendapatan suatu usaha khususnya pada Usaha Mikro, Kecil, dan Menengah (UMKM). Usaha Mikro, Kecil, dan Menengah (UMKM) merupakan salah satu usaha dimana pengembangan produk mereka sangat penting demi mendapatkan keuntungan yang optimal. Salah satu Teknologi Informasi yang sedang berkembang pesat dan sangat berpotensi dapat mendorong kinerja UMKM adalah media sosial.

The Hongkong and Shanghai Banking Corporation (2007) menyatakan bahwa UMKM di Indonesia sangat baik untuk dikembangkan. Karena sekitar $64 \%$ pengusaha UMKM mempunyai niat untuk menambah investasi pengembangan bisnis dan sekitar $44 \%$ pengusaha UMKM di Indonesia mempunyai rencana untuk menambah tenaga kerja (Rahmana,2009). Tahun 2009, tercatat ada lebih dari 6 juta masyarakat lokal yang ada disekitar lokasi usaha.

Usaha Mikro, Kecil dan Menengah (UMKM) menempati kedudukan strategis dalam perekonomian Banda Aceh. Data Kementerian Negara Koperasi dan UKM 2008 menunjukkan kontribusi signifikan UMKM secara nasional. Pertama, industri UMKM dalam sektor ekonomi menjangkau 99,9\% dari total unit usaha. Kedua, kemampuan UMKM dalam menyerap tenaga kerja mencapai $97,04 \%$ dari total angkatan kerja yang bekerja. Ketiga, UMKM menyumbang 55,56\% dalam pembentukan produk domestik bruto (PDB).

UMKM di Kota Banda Aceh telah berkembang pesat dan menunjukkan peran pentingnya dalam perekonomian Kota Banda Aceh. Data tahun 2017 UMKM berjumlah 8.405 unit atau sampai dengan 3,4 persen dari jumlah populasi penduduk Kota Banda Aceh. UMKM di Kota Banda Aceh memberikan arti yang penting dimana dalam menyediakan sumber daya mata pencaharian masyarakat. Untuk mengurangi angka pengangguran di Kota Banda Aceh, UMKM merupakan salah satu alternatif untuk menciptakan lapangan pekerjaan, akan tetapi untuk mengoptimalkan UMKM terhadap perekonomian sangat bergantung pada nilai produktivitas dan kreatifitas pengembangan usaha dari pengusaha itu sendiri (Nazaruddin, 2015 dalam Nurrahman, 20117).

Mengingat pentingnya peran UMKM tersebut seharusnya pada era teknologi dimana informasi bergerak sangat cepat dan menjadi pelaku bisnis untuk memenangkan persaingan TI dapat menjadi peluang bagi UMKM untuk memasarkan produknya dan menumbuhkan jaringan usaha di seluruh belahan dunia usaha, tidak saja hanya digunakan oleh perusahaan-perusahaan besar. Pemanfaatan Teknologi Informasi di Kota Banda Aceh sudah mengalami peningkatan yang baik, meskipun peningkatan tersebut masih rendah.

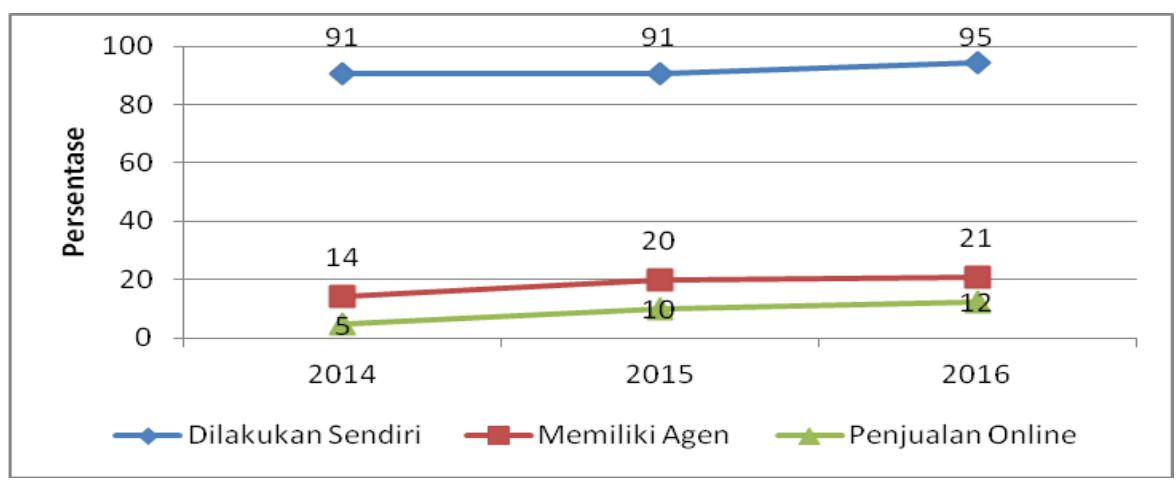

Jurnal Ilmiah Mahasiswa Pertanian, Volume 5, No.4, November 2020 
Gambar 1. Cara memasarkan produk UMKM Kota Banda Aceh $(O V O P, 2016)$

Gambar 1 menjelaskan pemanfaatan Teknologi Informasi berbentuk penjualan online yang disebut juga dengan e-commerce terjadi peningkatan pada setiap tahunnya, dimulai pada angka 4,62\% hingga 12,23\%. Akan tetapi dapat kita lihat bahwasanya peningkatan tersebut masih rendah diantara cara pemasaran dilakukan sendiri dan agen.

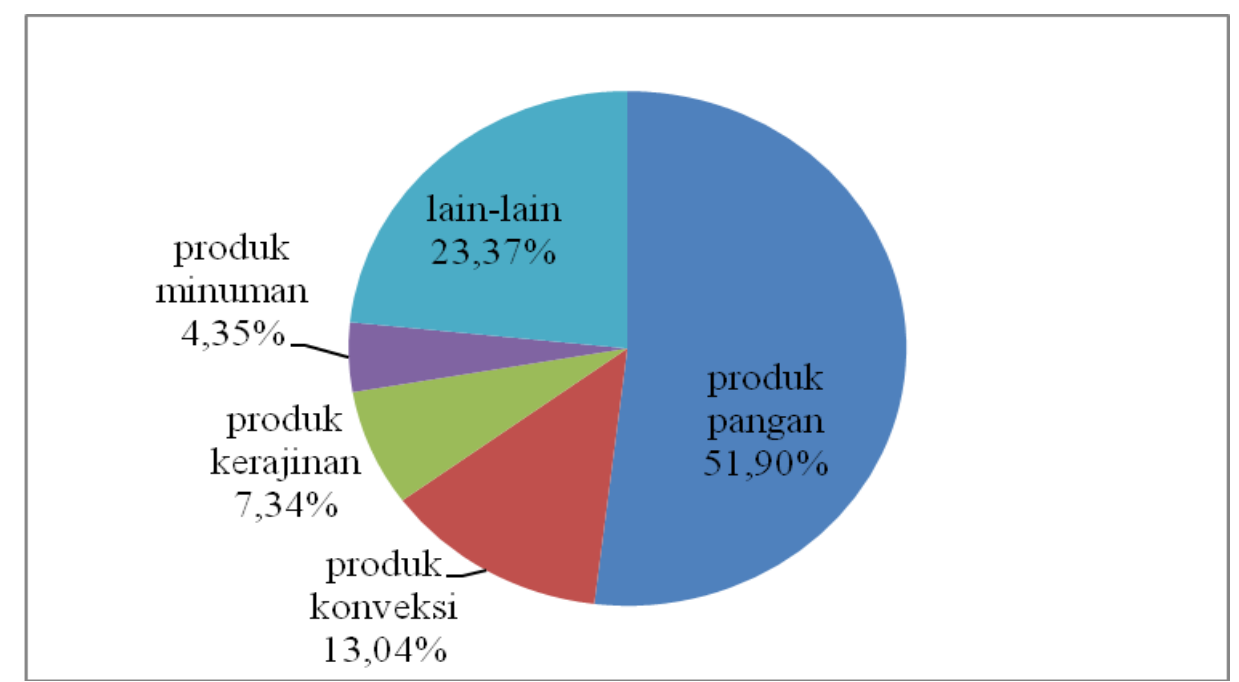

Gambar 2. Persentase produk UMKM Kota Banda Aceh (OVOP, 2016)

UMKM produk pangan merupakan salah satu UMKM yang sangat besar jumlah produknya. Pada Gambar 2 dapat dilihat persentase produk pangan lebih besar dari pada produk lainnya. Produk pangan memberikan kontribusi sebesar 51,90\% atau sebanyak 191 produk. Sedangkan produk yang lain lebih sedikit persentase jumlah produknya. Selanjutnya keterbatasan modal juga disebabkan sulitnya memperoleh kredit karena jenis usaha UMKM produk pangan yang tidak bankable (seperti pada komoditas pertanian) (Waluyo dan Djauhari, 1992 dalam Djoni dan Rohman, 2010). Tetapi dengan Teknologi Informasi produk-produk UMKM dapat dipasarkan dan dipromosikan secara luas kepada konsumen, baik itu lokal, nasional, maupun internasional sehingga memudahkan UMKM untuk mengajukan peminjaman modal karena dinilai usaha tersebut telah layak dikarenakan produk-produknya telah dikenal secara luas dan menjadikan usaha yang bankable walaupun dinilai UMKM merupakan usaha yang tidak sustainable (berkelanjutan). UMKM produk pangan di Kota Banda Aceh berpotensi dalam memanfaatkan Teknologi Informasi tersebut dikarenakan produknya yang sangat mudah bersaing dan sulit untuk memasarkan produknya kepada konsumen. Kejadian saat ini UMKM produk pangan di Kota Banda Aceh hanya memasarkan produknya dari mulut ke mulut dan pada pasar lokal umumnya juga dibantu oleh agen pemasaran.

Efektivitas pemanfaatan teknologi informasi berbasis e-commerce pada Usaha Mikro, Kecil, dan Menengah (UMKM) seharusnya ditinjau untuk mengetahui keefektifan teknologi informasi tersebut. Apabila pelaku UMKM sudah menggunakan e-commerce untuk mencapai tujuan maka UMKM tersebut dikatakan efektif. Pentingnya peran UMKM produk pangan di Kota Banda Aceh dan pemanfaatan Teknologi Informasi berbasis $e$ commerce perlu adanya kajian yang lebih jauh. Fenomenanya derasmya arus informasi dan semakin bebasnya kompetisi telah meningkatkan kesadaran konsumen dan pelanggan akan banyaknya pilihan produk barang dan jasa yang dapat dipilih. Dengan memanfaatan 
Teknologi Informasi akan mendorong UMKM dapat membangun hubungan jangka panjang dengan konsumen dan pelanggan serta mendapatkan peluang ekspor, peningkatan volume penjualan produk, pemasaran dan promosi produk yang meluas serta peluang bisnis lainnya.

\section{METODE PENELITIAN}

Penelitian ini dilaksanakan di Kota Banda Aceh dan penelitian ini dilaksanakan pada bulan Desember 2018-Januari 2019 dengan 30 sampel. Teknik penentuan sampel dilakukan dengan sengaja (purposive sampling). Metode penelitian yang digunakan adalah metode deksriptif pendekatan kuantitatif. Metode pengumpulan data yaitu menggunakan kuesioner, wawancara dan observasi. Pengolahan data meliputi editing, coding dan tabulasi. Metode analisis data dalam penelitian ini adalah analisis deksriptif frekuensi dengan rumus sebagai berikut :

$$
\mathrm{P}=\frac{F}{N} \times 100 \%
$$

Keterangan :

P : Persentase Jawaban

$\mathrm{F} \quad$ : Frekuensi nilai yang diperoleh dari seluruh item

$\mathrm{N} \quad$ : Jumlah Responden

$100 \%$ : Bilangan tetap

\section{HASIL PENELITIAN DAN PEMBAHASAN}

\section{Dukungan Pemerintah}

\section{Persentase Dukungan Pemerintah}

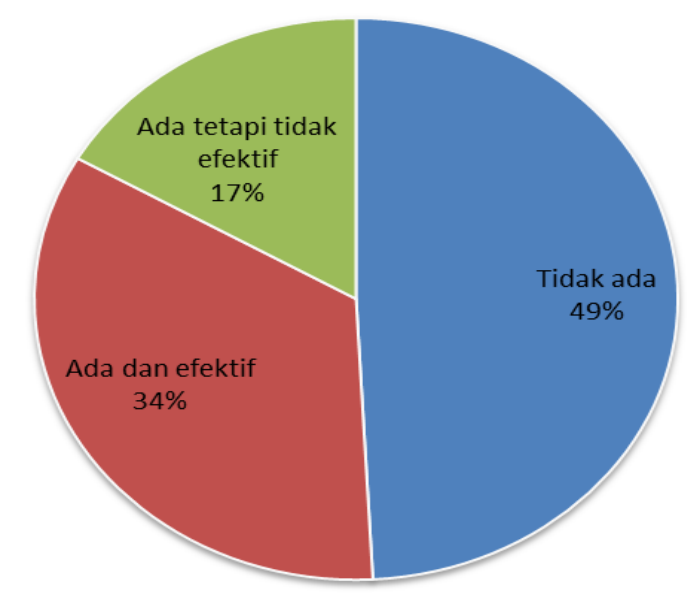

Gambar 3. Persentase dukungan pemerintah dalam pemanfaatan Teknologi Informasi berbasis e-commerce pada UMKM Produk Pangan di Kota Banda Aceh (Sumber: Data Primer (diolah), 2019) 
Berdasarkan hasil penelitian pada Gambar 3, secara umum dapat disimpulkan bahwa dukungan pemerintah pada Usaha Mikro Kecil dan Menengah (UMKM) produk pangan di Kota Banda Aceh masih minim. Hal tersebut dapat dilihat pada Gambar diatas, sebesar 49\% yang menganggap bahwa tidak ada dukungan pemerintah. Sedangkan $34 \%$ menjawab ada dan efektif dukungan pemerintah dalam pemanfaatan Teknologi Informasi berbasis e-commerce, dan sebesar $17 \%$ menjawab ada dukungan pemerintah tetapi tidak efektif. Dukungan pemerintah dianggap masih minim oleh responden karena progressnya masih sangat lambat terhadap pemanfaatan teknologi informasi berbasis $e$-commerce pada UMKM produk pangan di Kota Banda Aceh. Responden juga menjelaskan bahwa penyebaran informasi tidak dilakukan secara merata, sehingga beberapa pelaku UMKM tidak mengetahui adanya dukungan pemerintah terhadap UMKM.

\section{Infrastruktur}

\section{Persentase infrastruktur}

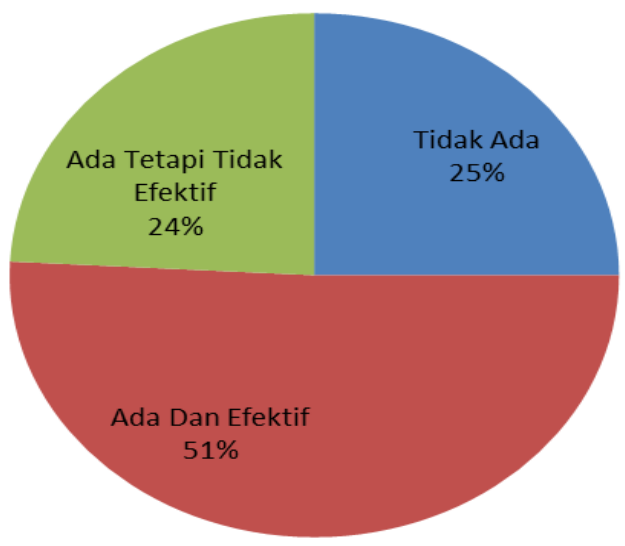

Gambar 4. Persentase infrastruktur dalam pemanfaatan Teknologi Informasi berbasis $e$ commerce pada UMKM Produk Pangan di Kota Banda Aceh (Sumber: Data Primer (diolah), 2019)

Berdasarkan hasil penelitian pada Gambar 4, secara umum dapat disimpulkan bahwa infrastruktur dalam pemanfaatan Teknologi Informasi berbasis e-commerce pada UMKM Produk Pangan di Kota Banda Aceh dalam dianggap sudah baik. Hal tersebut dapat dilihat pada Gambar diatas, sebesar 51\% yang menjawab infrastruktur "ada dan efektif". Sedangkan $25 \%$ dari total responden menjawab "tidak ada" pada infrastruktur. Dan sebesar $24 \%$ dari total responden menjawab "ada tetapi tidak efektif". Infrastruktur dianggap baik bagi pelaku UMKM di Kota Banda Aceh dikarenakan sarana dan prasarana telah dirasakan dan dapat dimanfaatkan dengan baik, adapun jaringan teknologi maupun alat Teknologi Informasi serta sarana pembangunan listrik dan tower jaringan yang sudah berkembang dan tersebar secara menyeluruh di Kota Banda Aceh. Karena dalam pemanfaatan Teknologi Informasi dibutuhkan jaringan serta sumber daya listrik yang baik sebagai penunjang dalam penggunaan teknologi tersebut. Berikut akan dijelaskan hasil jawaban dominan per pernyataan yang telah diajukan kepada responden. 


\section{Sumberdaya Manusia}

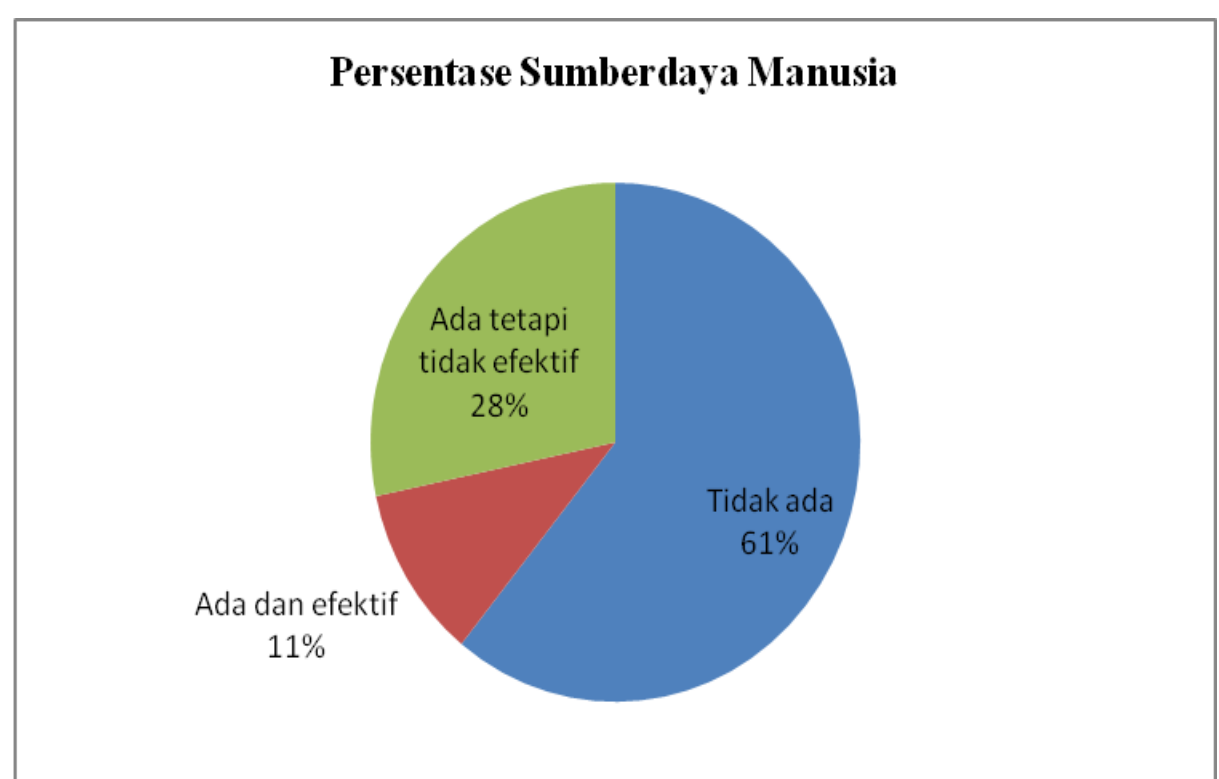

Gambar 5. Persentase sumber daya manusia pada pemanfaatan Teknologi Informasi berbasis E-commerce pada Usaha Mikro, Kecil dan Menengah (UMKM) produk pangan di Kota Banda Aceh (Sumber: Data Primer (diolah), 2019)

Berdasarkan hasil penelitian, pada Gambar 5 secara umum dapat disimpulkan bahwa sumber daya manusia pada Usaha Mikro Kecil dan Menengah (UMKM) produk pangan di Kota Banda Aceh dianggap masih rendah. Dapat dilihat pada Gambar tersebut, sebesar $61 \%$ responden menjawab "tidak ada". Sedangkan $28 \%$ dari total responden menjawab "ada tetapi tidak efektif". Dan sebesar $11 \%$ dari total responden menjawab "ada dan efektif". Sumber daya manusia dianggap rendah karena masih banyak pelaku UMKM produk pangan yang tidak mengerti dan tidak memahami tentang pemanfaatan Teknologi Informasi yang canggih ini. Berikut akan dijelaskan hasil jawaban dominan per pernyataan yang telah diajukan kepada responden.

\section{SIMPULAN DAN SARAN}

\section{SIMPULAN}

Berdasarkan hasil penelitian yang telah dilakukan mengenai efektivitas pemanfaatan Teknologi Informasi berbasis e-commerce pada UMKM produk pangan di Kota Banda Aceh, dapat disimpulkan bahwa secara umum indikator dukungan pemerintah dianggap masih rendah. Dianggap masih rendah karena progressnya masih sangat lambat terhadap pemanfaatan teknologi informasi berbasis e-commerce pada UMKM produk pangan di Kota Banda Aceh.

Indikator infrastruktur dalam pemanfaatan Teknologi Informasi berbasis e-commerce dianggap sudah efektif. Dianggap sudah efektif dikarenakan sarana dan prasarana telah dirasakan dan dapat dimanfaatkan oleh pelaku UMKM. Indikator sumber daya manusia dalam pemanfaatan Teknologi Informasi berbasis e-commerce dianggap masih rendah. Hal 
tersebut terjadi karena masih banyak pelaku UMKM produk pangan yang tidak mengerti dan tidak memahami tentang pemanfaatan Teknologi Informasi yang canggih ini.

\section{SARAN}

Beberapa saran yang dapat diberikan setelah dilakukan penelitian yaitu :

1. Diharapkan kepada pemerintah agar mengadakan pelatihan/training dan workshop/seminar kepada pelaku UMKM supaya dapat mengetahui teknologi informasi berbasis e-commerce. Diharapkan juga kepada pemerintah agar memberikan kebijakan dan bantuan modal kepada pelaku UMKM untuk mengembangkan usaha produk pangan di Kota Banda aceh.

2. Diharapkan kepada pelaku UMKM agar memiliki alat-alat teknologi informasi sebagai penunjang pada usaha produk pangan. Diharapkan juga kepada pelaku UMKM untuk meningkatkan kesadaran dan minat, dapat memahami cara memasarkan produk, mampu mengoperasikan alat Teknologi Informasi dan meluangkan waktu serta biaya untuk pemanfaatan Teknologi Informasi berbasis $e$ commerce pada Usaha Mikro, Kecil, dan Menengah produk pangan di Kota Banda Aceh.

\section{DAFTAR PUSTAKA}

Ang, Robert. 1997. Buku Pintar Pasar Modal Indonesia. Media Indonesia. Jakarta.

Arikunto, S. 2002. Metodologi Penelitian Suatu Pendekatan Proposal. PT. Rineka Cipta. Jakarta.

Arikunto, S. 2006. Prosedur Penelitian Suatu Pendekatan Praktek. PT. Rineka Cipta. Jakarta

Arisandi, Y.T. 2014. Evektivitas Penerapan E-commerce dalam Perkembangan Usaha Kecil dan Menengah di Sentra Industri Sandal dan Sepatu Wedoro Kabupaten Sidoarjo. Fakultas Ilmu Sosial. Universitas Airlangga.

Baum, D. 1999. E-commerce. PT. Gramedia Pustaka Utama. Jakarta.

Delima, Z. M., \& Zuliyati, Z. 2018. Pengaruh Intellectual Capital Terhadap Bussines Performance Umkm Di Kabupaten Kudus. Jurnal Bingkai Ekonomi, 3(1), 43-49.

Djoni, D., \& Rohman, M. (2010). Pemahaman Petani Dalam Menerapkan Prinsip 5-c Kaitannya Dengan Pengembalian Kredit Bidang Agribisnis. Jurnal Keuangan dan Perbankan, 14(2), 345-361.

Eva, A. 2007. Persepsi penggunaan aplikasi internet untuk pemasaran produk usaha kecil menengah. Seminar Nasional Aplikasi Teknologi Informasi (SNATI). ISSN : 19075022.

Fathoni, A. 2001. Ilmu Sumber Daya Manusia. PT. Rineke Cipta. Jakarta.

Fuadi, M. 2005. Pengantar Hukum Bisnis : Menata Bisnis Modern di Era Globalisasi, Edisi Kedua. PT. Citra Aditya Bakti. Bandung.

Hamdani, A. H., \& Awatara, I. G. P. D. 2015. Faktor-faktor yang mempengaruhi upgrading UMKM di Kota Surakarta. In Prosiding Seminar Nasional 4th UNS SME's Summit \& Awards (pp. 176-183).

Hapsari, R. N. 2013. Kontribusi Makanan Jajanan terhadap tingkat Kecukupan Asupan Energi dan Protein Pada Anak Sekolah yang Mendapat PMT-AS Di SD Negeri Plalan 1 Kota Surakarta (Doctoral dissertation, Universitas Muhammadiyah Surakarta).

Hasan, I. 2006. Analisis Data Penelitian dengan Statistik. Bumi Aksara. Jakarta. 
Herawati, T., Ginting, B., Asngari, P. S., Susanto, D., \& Puspitawati, H. 2011. Ketahanan pangan keluarga peserta program pemberdayaan masyarakat di Pedesaan. Jurnal gizi dan pangan, 6(3), 208-216.

Iqbal, H. 2006. Analisis Data Penelitian Dengan Statistik. Bumi Aksara. Jakarta.

Irmawati. 2011. Pemanfaatan e-commerce dalam dunia bisnis. Jurnal Ilmiah Orasi Bisnis. Edisi ke VI. ISSN : 2085-1375. Palembang.

Jakaria, Y. 2007. Studi Pemetaan Kemampuan Teknologi Informasi (TI) di Pendidikan Dasar dan Menengah di Indonesia. Jurnal Pendidikan dan Kebudayaan, 13 (66), 488-507.

Jauhari, J. 2010. Upaya pengembangan usaha kecil dan menengah (UKM) dengan memanfaatkan e-commerce. Jurnal Sistem Informasi (JSI). 2(1) : 159-168. . 2014. Upaya Pengembangan Usaha Kecil Dan Menengah (UKM) Dengan Memanfaatkan E-Commerce. Jurnal Sistem Informasi, 2(1).

Kalakota, R and Whinton, A.B. 1997. Electronic Commerce: A Managers Guide. New Jersey: Addison Wesley Profesional.

Kota Banda Aceh Dalam Angka. 2019. Kota Banda Aceh Dalam Angka. Badan Pusat Statistik. Banda Aceh.

Laudon, J., dan Laudon, K. C. 1998. Essensial of Management Information System. Prentice Hall. New Jersey.

Lubis, T dan Junaidi, J. 2016. Pemanfaatan Teknologi Informasi pada usaha mikro kecil dan menengah di kota Jambi. Jurnal Perspektif Pembiayaan dan Pembangunan Daerah. 3(3) : 163-174.

Mahalli, K. 2006. Usaha Kecil dan Menengah dan Penyerapan Tenaga Kerja. Wahana Hijau, 110.

Muhammad, S. 2016. One Village One Product (OVOP) : Produk UMKM Banda Aceh. Banda Aceh.

Muharrami, L. K. 2014. Kecenderungan Pilihan Jajanan Pangan Anak SD Terhadap Jajanan Berformalin. Jurnal Pena Sains, 1(2), 19-26.

Mujiyana dan Elissa, I. 2013. Analisis faktor-faktor yang mempengaruhi keputusan pembelian via internet pada toko online. J@TI Undip. 8(3) : 146-151.

Nugrahani, D.S. 2011. E-commerce untuk pemasaran produk usaha kecil dan menengah. SEGMEN Jurnal Manajemen dan Bisnis. (1) : 1-16.

Nugroho, N. T. 2016. Pengaruh penggunaan teknologi informasi terhadap kinerja karyawan (studi kasus karyawan stmik duta bangsa). DutaCom Journal, 11(1), 1222.

Nugroho, W. 2008. Keperawatan Gerontik. EGC. Jakarta.

Nurrahman, T. S. M. (2017). Analisis Usaha Mikro Kecil Dan Menengah (Umkm) Sektor Perdagangan Di Kota Banda Aceh. Jurnal Ilmiah Mahasiswa Ekonomi Pembangunan, 2(2), 320-328.

Prasetyo, M. T. 2018. Analisis Oligopoli Pada Industri E-Commerce Di Indonesia (Sebuah Pendekatan Teori SCP). Journal of Economics Development Issues, 1(1), 53-61.

Purbo, O. W. 2000. Mengenal E-commerce. PT Elex Media Komputendo. Jakarta.

Ramadhani, F., \& Arifin, Y. 2013. Optimalisasi Pemanfaatan Teknologi Informasi Komunikasi Berbasis E-commerce sebagai Media Pemasaran Usaha Kecil Menengah Guna Meningkatkan Daya Saing dalam Menghadapi Masyarakat Ekonomi ASEAN 2015. Economics Development Analysis Journal, 2(2). 
Rahmana, A. 2009. Peranan Teknologi Informasi dalam peningkatan daya saing usaha kecil menengah. Seminar Nasional Aplikasi Teknologi Informasi (SNATI). ISSN : 1907-5022. Yogyakarta.

Rahmati. 2009. Pemanfaatan e-commerce dalam bisnis di Indonesia. https://citozcome.bogspot.co.id/2009/05/pemanfaatan-e-commerce-dalam-bisnisdi.html (Diakses pada 17/04/2018).

Rosdhani, M. R., Purwo, A.W dan Anna, W. 2012. Analisis tingkat penggunaan Teknologi Informasi dan komunikasi pada usaha kecil menengah di kabupaten Jepara. Jurnal Dinamika Ekonomi dan Bisnis. 9(2) : 90-104.

Sandhausen, R. 2008. Marketing. hauppauge, N.Y: Barron's educational series. Page : 520. ISBN 0-7641-3932-0.

Saputro, P. D. 2015. Pemanfaatan E-Commerce Malltronik Dalam Proses Bisnis Bagi Pelaku Ikm.

Siregar, A. R. 2008. Penggunaan sistem dan Teknologi Informasi untuk Usaha Kecil dan Menengah.

Siregar, R. R. 2010. Strategi Meningkatkan Persaingan Bisnis Perusahaan dengan Penerapan E-Commerce. Trisakti. Jakarta.

Sudjana, N. 2001. Penelitian dan Penilaian Pendidikan. Sinar Baru. Bandung.

Sugiyono. 2010. Metode Penelitian Pendidikan Pendekatan Kuantitatif, Kualitatif dan $R \& D$. Alfabeta. Bandung.

Sugiyono. 2012. Metode Penelitian Kuantitatif, Kualitatif dan R\&D. Alfabeta. Bandung.

Tambunan, T. T. 2012. Peluang, Tantangan dan Ancaman bagi UMKM Indonesia dalam Era CAFTA dan ME-ASEAN 015. In Prosiding Seminar \& Konferensi Nasional Manajemen Bisnis: memberdayakan UMKM dalam meninkatkan kesejahteraan masyarakat menghadapi persaingan global (pp. 1-14). Badan Penerbit Universitas Muria Kudus.

Turban E dan Aronson, J. E. 2011. Decision Support Systems and Intellegent System : New Jersey. Prentice Hall.

Undang-Undang No. 20 pasal 1 dan Pasal 6 Tahun 2008 http://www.hukumonline.com/pusatdata/download/fl56041/node/28029. Diakses pada : 21/03/2018).

Wairisal, L. P., \& Khusniyah, N. 2012. Analisis Perilaku Penggunaan Teknologi Informasi (Studi pada Dosen Universitas Pattimura Ambon). Jurnal aplikasi manajemen, 10 (4), 761-771.

Wibowo, T. 2013. Pembuatan aplikasi e-commerce pusat oleh-oleh khas pacitan pada toko sari rasa pacitan. IJNS (Indonesian Journal on Networking and Security). 2(4) : 6267.

Wicaksono, B. 2015. Meningkatkan Potensi Pajak Umkm Online Melalui Data ECommerce.

Winidyaningrum, C. 2009. Pengaruh Sumber Daya Manusia Dan Pemanfaatan Teknologi Informasi Terhadap Keterandalan Dan Ketepatwaktuan Pelaporan Keuangan Pemerintah Daerah Dengan Variabel Intervening Pengendalian Intern Akuntansi (Studi Empiris di Pemda subosukawonosraten) (Doctoral dissertation, Universitas Sebelas Maret).

Yudiastra, P. P., \& Darma, G. S. 2015. Pengaruh Penggunaan Teknologi Informasi, Disiplin Kerja, Insentif, Turnover Terhadap Kinerja Pegawai. Jurnal Manajemen dan Bisnis, 12(1), 151-176. 
Zuhrah, F. 2011. Pentingnya Teknologi Informasi Dalam Meningkatkan Pelayanan di Perpustakaan. Jurnal Iqra, 5 (01).

Situs Web

https://pengertianahli.id/2013/11/pengertian-pangan-dan-jenis-jenis-pangan.html, diakses pada 12 Juli 2019. 